\title{
Effects of propofol on $\beta$-adrenoceptor-mediated signal transduction in cardiac muscle; role of cAMP
}

\author{
Chul Ho Chang, Go Un Roh, and Wyun Kon Park \\ Department of Anesthesiology and Pain Medicine, and Anesthesia and Pain Research Institute, Yonsei University College of \\ Medicine, Seoul, Korea
}

Background: Propofol may decrease myocardial contractility via actions on the $\beta$-adrenoceptor-mediated signal transduction. The aim of this study was to evaluate the effect of propofol via $\beta$-adrenoceptor-mediated signal transduction by measuring the tissue levels of cAMP (cyclic adenosine monophosphate).

Methods: The effects of propofol on $\beta$-adrenoceptor mediated cascades were measured with cAMP concentrations, which were stimulated by agonists (1-isoproterenol, GTP $\gamma$ S, and forskolin) of each step of $\beta$-adrenoceptor-mediated cascades.

Results: While the production of cAMP stimulated by isoproterenol, GTP $\gamma \mathrm{S}$, or forskolin are increased $(\mathrm{P}<0.05)$, application of each concentration of propofol $(0.1,1,10,100 \mu \mathrm{M})$ did not alter the levels of cAMP.

Conclusions: Considering that propofol did not alter the tissue cAMP levels when stimulated by isoproterenol, GTP $\gamma$ S, and forskolin, propofol appears to have no effect on the $\beta$-adrenoceptor signaling pathway in guinea pig ventricular myocardium. (Korean J Anesthesiol 2010; 58: 374-377)

Key Words: $\beta$-adrenoceptor, cAMP, G-protein, Propofol.

\section{Introduction}

Propofol is a widely used intravenous anesthetic with advantageous properties such as rapid induction and emergence. However, induction of anesthesia with propofol is often associated with a decrease in systemic arterial pressure.

At supraclinical concentrations which may occur during rapid bolus injection, a direct inhibitory effect of propofol on myocardial contraction in normal cardiac tissues of guinea pig [1-3] and ferret [4] as well as human atrial muscle [5] has been reported. Contributing factors on myocardial depression by propofol such as decreased $\mathrm{I}_{\mathrm{Ca}}$ (L-type $\mathrm{Ca}^{2+}$ current) via sarcolemma [6-8] and decreased $\mathrm{Ca}^{2+}$ uptake by the sarcoplasmic reticulum [9-11] have been proposed. Recently,

Received: October 6, 2009. Revised: 1st, October 30, 2009; 2nd, January 21, 2010. Accepted: February 18, 2010.

Corresponding author: Wyun Kon Park, M.D., Ph.D., Department of Anesthesiology and Pain Medicine, and Anesthesia and Pain Research Institute, Yonsei University College of Medicine, 134, Sinchon-dong, Seodaemun-gu, Seoul 120-752, Korea. Tel: 82-2-2227-4172, Fax: 82-2-3127185, E-mail:wkp7ark@yuhs.ac

This work was supported by the Yonsei University Research Fund of 2005 (6-2005-0091) and the faculty research grant of Yonsei University College of Medicine for 2005 (6-2005-0049).

(c) This is an open-access article distributed under the terms of the Creative Commons Attribution Non-Commercial License (http:// creativecommons.org/licenses/by-nc/3.0/), which permits unrestricted non-commercial use, distribution, and reproduction in any medium, provided the original work is properly cited. 
propofol has been reported to have direct inhibitory effects on $\beta$-adrenoceptor signal transduction, which may cause contractile depression in cardiac muscle [12]. However, the cellular mechanism has not been well-defined.

$\beta$-adrenoceptor stimulated by l-isoproterenol binds to $\beta$-adrenergic receptor and produce an interaction between $\beta$-adrenergic receptor and Gs (stimulatory G-protein), which enhances adenylyl cyclase activity. Adenylyl cyclase is a membrane-bound enzyme that converts intracellular adenosine phosphate (ATP) to cAMP, a second messenger in the signal transduction system. cAMP activates cAMP-dependent protein kinase (A-kinase), resulting in phosphorylation of particular proteins. Increased cAMP prolongs the opening time of $\mathrm{Ca}^{2+}$ channels, resulting in increased $\mathrm{Ca}^{2+}$ entry and positive inotropic effect. Inhibitory effects on the signal transduction pathway may also result in negative inotropic effect.

Therefore, we evaluated the effect of propofol on tissue cAMP levels via $\beta$-adrenoceptor-mediated signal transduction using $\beta$-adrenoceptor agonist, G-protein stimulant, and adenylyl cyclase agonist.

\section{Materials and Methods}

\section{Myocardial membrane preparation and quantitative analysis}

The heart was excised from male guinea pigs (250-300 g) anesthetized with sevoflurane at $3-4$ vol\% according to a procedure approved by the Institutional Animal Research Committee. Blood was evacuated and the hearts were kept in icecold buffer ( $0.25 \mathrm{M}$ sucrose, $5 \mathrm{mM}$ Tris/HCl, $1 \mathrm{mM} \mathrm{MgCl}_{2} ; \mathrm{pH}$ 7.4) aerated with $100 \% \mathrm{O}_{2}$. Atrium, aorta, and other extraneous tissues were removed. Two hearts were homogenized with five volumes of ice-cold buffer, transferred into a $15 \mathrm{ml}$ conical tube, and centrifuged at $600 \mathrm{~g}$ for 10 minutes at $4^{\circ} \mathrm{C}$. The supernatant was divided into six to eight $1.5 \mathrm{ml}$ microcentrifuge tubes, and centrifuged at $15,000 \mathrm{~g}$ for 10 minutes at $4^{\circ} \mathrm{C}$. The supernatant was centrifuged again at $100,000 \mathrm{~g}$ for 60 minutes at $4^{\circ} \mathrm{C}$. The membrane pellet was dissolved in $1 \mathrm{ml}$ of ice-cold incubation buffer (mM: 50 Tris/ $\mathrm{HCl}, 10 \mathrm{MgCl}_{2} ; \mathrm{pH} 7.5$ ) and used for quantitative analysis. Quantitative analysis was performed with Biochronic Acid Assay (BCA) kit (Pierce, Rockford, IL, USA). Protein concentration was measured by the method of Lowry [13], using a bovine serum albumin $(0,0.25,0.5,0.75,1.0 \mathrm{mg} / \mathrm{ml})$. About 3-4 mg/ml of membranous protein was achieved and kept at $-20^{\circ} \mathrm{C}$ after freezing with liquid nitrogen.

\section{Measurement of cAMP concentration}

Each of $0.1,1,10$, and $100 \mu \mathrm{M}$ propofol, l-isoproterenol (0.1 $\mu \mathrm{M})$ or forskolin $(3 \mu \mathrm{M})$ or GTP $\gamma \mathrm{S}$ [guanosine 5"-O-(3-thiotriphosphate) $(1 \mu \mathrm{M})$ and the membranous protein $(250 \mu \mathrm{g})$ were added to cAMP production buffer (mM: $2.5 \mathrm{Na}_{2} \mathrm{ATP}, 5$ $\mathrm{MgCl}_{2}$, 1 Tris-EGTA, 20 creatine phosphate, $50 \mathrm{U} / \mathrm{ml}$ creatine phosphokinase, 0.8 IBMX, 50 Tris/ $\mathrm{HCl}, \mathrm{pH} 7.5$ ) in a total volume of $500 \mu \mathrm{l}$. In the preliminary experiments, we determined the concentrations of these three stimulants which showed maximum tissue levels of cAMP.

To exclude the effect of DMSO on cAMP levels, the concentrations of DMSO used for forskolin were tested. After 10-min incubation at $37^{\circ} \mathrm{C}$, the reaction was stopped with $100^{\circ} \mathrm{C}$ heat, and the sample was centrifuged at $6,000 \mathrm{~g}$ for 20 minutes at $4^{\circ} \mathrm{C}$. The cAMP concentration in the supernatant was measured using a cAMP assay kit [cAMP Biotrak Enzymeimmunoassay (EIA) System, Amersham, UK].

Working standard was prepared using the standard for acetylation assay, anti-serum, cAMP peroxidase conjugate and wash buffer provided by cAMP assay kit. Samples were diluted 100 times in assay buffer [0.05 M sodium acetate ( $\mathrm{pH} 5.8$ ), $0.02 \%$ bovine serum albumin, $0.01 \%$ preservative]. Acetylation reagent mixed with two volumes of triethylamine and one volume of acetic anhydride was added to all standards (0-128 fmol) and samples. One hundred $\mu \mathrm{l}$ of cAMP antiserum was added to 96 well plates coated with secondary antibody (except blank and non-specific binding wells), and $50 \mu \mathrm{l}$ of samples or acetylation standard were added to each well. Assay buffer alone $(150 \mu \mathrm{l})$ was added to non-specific binding wells. Plates were incubated for 60 minutes at $4^{\circ} \mathrm{C}$. cAMP peroxidase conjugate $(100 \mu \mathrm{l})$ was added to all wells except blanks and plates were incubated for 60 minutes at $4^{\circ} \mathrm{C}$. Wells were aspirated and washed 4 times with $400 \mu \mathrm{l}$ wash buffer and TMB substrate $(150 \mu \mathrm{l})$ was added. After 1-hour shaking at room temperature, the reaction was stopped with $1 \mathrm{M}$ sulfuric acid (100 $\mu \mathrm{l})$. cAMP concentration was measured at $450 \mathrm{~nm}$ with a spectrophotometer (ELISA Reader, Versamax, Molecular Devices, Union City, CA, USA). The experiment was performed in duplicate.

\section{Statistical analysis}

One-way ANOVA followed by the Student-Newman-Keuls test was applied to test for the significant differences among control and drug applications. All values were expressed as mean \pm SD. A P value less than 0.05 was considered significant.

\section{Results}

Whereas tissue cAMP levels produced by isoproterenol $(0.1 \mu \mathrm{M})$, GTP $\gamma \mathrm{S}(1 \mu \mathrm{M})$, and forskolin $(3 \mu \mathrm{M})$ in guinea pig myocardium were increased when compared to baseline values before treatment of each stimulant, application of propofol $(0.1,1$, 
Table 1. Effects of Propofol on Cyclic Adenosine Monophosphate Production Stimulated by l-isoproterenol, GTP $\gamma \mathrm{S}$ [Guanosine 5"-O-(3-Thiotriphosphate)], and Forskolin

\begin{tabular}{llll}
\hline $\begin{array}{c}\text { Propofol } \\
\text { concentration } \\
(\mu \mathrm{M})\end{array}$ & $\begin{array}{c}\text { Isoproterenol } \\
(0.1 \mu \mathrm{M})\end{array}$ & $\begin{array}{c}\mathrm{GTP} \gamma \mathrm{S} \\
(1 \mu \mathrm{M})\end{array}$ & $\begin{array}{c}\text { Forskolin } \\
(3 \mu \mathrm{M})\end{array}$ \\
\hline Control & $180 \pm 24$ & $225 \pm 199$ & $250 \pm 125$ \\
0 & $273 \pm 63^{*}$ & $314 \pm 142^{*}$ & $684 \pm 115^{*}$ \\
0.1 & $277 \pm 71^{*}$ & $311 \pm 143^{*}$ & $695 \pm 109^{*}$ \\
1 & $240 \pm 57^{*}$ & $304 \pm 157^{*}$ & $692 \pm 119^{*}$ \\
10 & $270 \pm 70^{*}$ & $310 \pm 152^{*}$ & $685 \pm 119^{*}$ \\
100 & $266 \pm 27^{*}$ & $278 \pm 170^{*}$ & $678 \pm 112^{*}$ \\
\hline
\end{tabular}

Control indicates baseline values before treatment of isoproterenol, GTP $\gamma$ S, and forskolin, respectively. The units of cAMP values are $\mathrm{fmol} / \mathrm{mg}$ protein. Results are mean $\pm \mathrm{SD}$. $* \mathrm{P}<0.05$ vs. control.

10 , and $100 \mu \mathrm{M}$ ) did not alter the tissue cAMP levels when stimulated by isoproterenol $(\mathrm{n}=10), \operatorname{GTP} \gamma \mathrm{S}(\mathrm{n}=6)$, and forskolin ( $n=6)$ (Table 1) (NS).

DMSO $(3 \mu \mathrm{M})$ did not produce any change in the tissue cAMP levels ( $n=8$, NS) (control: $489 \pm 183 \mathrm{fmol} / \mathrm{mg}$ protein).

\section{Discussion}

This study shows that either clinically relevant or supraclinical concentrations of propofol have no effect on the tissue cAMP levels evoked by $\beta$-adrenoceptor stimulation (l-isoproterenol), G-protein stimulation (GTP $\gamma \mathrm{S}$ ), and adenylyl cyclase stimulation (forskolin).

In vitro studies using normal cardiac tissue have reported that propofol has negative inotropic effect in guinea pig [1-3] and ferret [4] ventricular myocardium as well as in human atrial muscles [5] at supraclinical concentrations. However, at clinically relevant concentrations, most in vitro studies indicate that propofol exerts little negative inotropic effect $[1,9,10]$. At supraclinical concentrations, myocardial depression by propofol has been attributed to decreased $\mathrm{I}_{\mathrm{Ca}}$ via sarcolemma [6-8] and decreased $\mathrm{Ca}^{2+}$ uptake by the sarcoplasmic reticulum [9-11]. However, clinically relevant doses of propofol $(0.1-10 \mu \mathrm{M})$ had no significant effect on steady state $\mathrm{I}_{\mathrm{Ca}}[14]$. Clinical concentrations after induction with propofol range from $2 \mu \mathrm{g} / \mathrm{ml}(11.2 \mu \mathrm{M})$ to $15 \mu \mathrm{g} / \mathrm{ml}(84 \mu \mathrm{M})$ [15]. Considering that protein binding of propofol exceeds $95 \%$, free fractions of propofol are less than 1 $\mu \mathrm{g} / \mathrm{ml}(5.6 \mu \mathrm{M})$.

Zhou et al. [12] in their study using rat ventricular myocardium demonstrated that relatively high concentrations of propofol $(25-200 \mu \mathrm{M})$ antagonized $\beta$-adrenoceptor binding. Although these results suggest direct inhibitory effects of propofol on $\beta$-adrenoceptor signal transduction, the mechanism at the cellular level has not been well elucidated. In rat cardiomyocytes, Kurokawa et al. [14] demonstrated that clini- cally relevant concentrations of propofol $(0.1-10 \mu \mathrm{M})$ had no significant effect on steady state $\mathrm{I}_{\mathrm{Ca}}$ but attenuated the increased $\mathrm{I}_{\mathrm{Ca}}$ induced by isoproterenol. In their cAMP experiments, whereas propofol attenuated the isoproterenol-induced increase in cAMP production, propofol did not alter the increase in cAMP induced by direct activation of adenylyl cyclase with forskolin. Therefore, they proposed that the inhibitory site of action of propofol is upstream of adenylyl cyclase. These results indicate that propofol-induced depression of the isoproterenolstimulated increase in $\left[\mathrm{Ca}^{2+}\right]_{\mathrm{i}}$ and shortening of cardiomyocytes are mediated by a decrease in $\mathrm{I}_{\mathrm{Ca}}$, which suggest that propofol interferes with the $\beta$-adrenergic pathway. In contrast, in guinea pig ventricular tissues, we did not observe any attenuation of increased tissue cAMP levels induced by isoproterenol at either clinically relevant or supraclinical concentrations of propofol. The inhibitory potency of propofol in myocardial contractility at supraclinical concentrations has been reported in guinea pig ventricular papillary muscles $[1,3,4]$. In contrast, propofol, at either clinically relevant or supraclinical concentrations, was devoid of substantial negative inotropic action in rat papillary muscle [1,9]. Whereas Azuma et al. [1], in their study using rat and guinea pig ventricular myocardium, observed that supraclinical concentrations of propofol $(600 \mu \mathrm{M})$ caused modest shortening of action potential duration, significant shortening was shown in guinea pig preparations, which suggests species difference in sensitivity of $\mathrm{I}_{\mathrm{Ca}}$ to propofol. Considering these different results, species difference may account for the discrepancies observed in the tissue levels of cAMP.

In conclusion, considering that propofol did not alter the tissue cAMP levels when stimulated by isoproterenol, GTP $\gamma \mathrm{S}$, and forskolin, propofol appears to have no effect on the $\beta$-adrenoceptor signaling pathway in guinea pig ventricular myocardium.

\section{References}

1. Azuma M, Matsumura C, Kemmotsu O. Inotropic and electrophysiologic effects of propofol and thiamylal in isolated papillary muscles of guinea pig and the rat. Anesth Analg 1993; 77: 557-63.

2. Park WK, Lynch C III. Propofol and thiopental depression of myocardial contractility. Anesth Analg 1992; 74: 395-405.

3. Stowe DF, Bosnjak ZJ, Kampine JP. Comparison of etomidate, ketamine, midazolam, propofol, and thiopental on function and metabolism of isolated hearts. Anesth Analg 1992; 74: 547-58.

4. Cook DJ, Housmans PR. Mechanism of the negative inotropic effect of propofol in isolated ferret ventricular myocardium. Anesthesiology 1994; 80: 859-71.

5. Gelissen HP, Epema AH, Henning RH, Krijnen HJ, Hennis PJ, den Hertog A. Inotropic effects of propofol, thiopental, midazolam, etomidate, and ketamine on isolated human atrial muscle. Anesthesiology 1996; 84: 397-403.

6. Buljubasic N, Marijic J, Berczi V, Supan DF, Kampine JP, Bosnjak 
ZJ. Differential effects of etomidate, propofol, and midazolam on calcium and potassium channel currents in canine myocardial cells. Anesthesiology 1996; 85: 1092-9.

7. Zhou W, Fontenot HJ, Liu S, Kennedy RH. Modulation of cardiac calcium channels by propofol. Anesthesiology 1997; 86: 670-5.

8. Yang CY, Wong CS, Yu CC, Luk HN, Lin CI. Propofol inhibits cardiac L-type calcium currents in guinea pig ventricular myocytes. Anesthesiology 1996; 84: 626-35.

9. Riou B, Besse S, Lecarpentier Y, Viars P. In vitro effects of propofol on rat myocardium. Anesthesiology 1992; 76: 609-16.

10. Kanaya N, Murray PA, Damron DS. Propofol and ketamine only inhibit intracellular $\mathrm{Ca}^{2+}$ transients and contraction in rat ventricular myocytes at supraclinical concentrations. Anesthesiology 1998; 88: 781-91.

11. Guenoun T, Montagne O, Laplace M, Crozatier B. Propofol-induced modifications of cardiomyocyte calcium transient and sarcoplasmic reticulum function in rats. Anesthesiology 2000; 92: 542-9.

12. Zhou W, Fontenot HJ, Wang SN, Kennedy RH. Propofol-induced alterations in myocardial $\beta$-adrenoceptor binding and responsiveness. Anesth Analg 1999; 89: 604-8.

13. Lowry OH, Rosenbrough NJ, Farr AL, Randall RJ. Protein measurement with Folin phenol reagent. J Biol Chem 1951; 193: 265-75.

14. Kurokawa H, Murray PA, Damron DS. Propofol attenuates $\beta$ adrenoreceptor-mediated signal transduction via a protein kinase c-dependent pathway in cardiomyocytes. Anesthesiology 2002; 96: 688-98.

15. Shafer A, Doze VA, Shafer SL, White PF. Pharamcokinetics and pharmacodynamics of propofol infusions during general anesthesia. Anesthesiology 1988; 69: 348-56. 